Iztok Šori

\title{
JILL REYNOLDS THE SINGLE WOMAN: AN DISCURSIVE INVESTIGATION
}

London, New York: Routledge, 2008. 182 strani.

Monografija Jill Reynolds, profesorice na Fakulteti za zdravje in socialno delo (Open University, Velika Britanija), je feministična diskurzivna analiza samskosti kot identitete. Utemeljena je na tridesetih intervjujih s samskimi ženskami in predpostavki, da je samskost spolno specifična družbena kategorija, ki deluje drugače za moške in ženske.

Avtoričin pristop je inovativen in odstopa od uveljavljenih empiričnih analiz, ki so večinoma osnovane na statističnih podatkih in anketnih vprašalnikih. Tako se denimo sprašuje: kako samske ženske skozi govor osmišljajo samskost in partnerske odnose? Kako novi in različni kulturni resursi, ki jih ženske uporabljajo v svojem govoru, sovpadajo z bolj zgodovinskimi diskurzi o položaju žensk? Kako ženske razumejo lastno delovanje in možnosti izbire v odnosu do svoje samskosti? Kakšni odnosi moči oblikujejo njihovo izkušnjo samskosti? Kako ženske retorično ravnajo s stigmatiziranimi vidiki samskosti? In nenazadnje, kakšne oblike skupinskih in osebnih strategij so v pomoč ženskam, da se prilagodijo kulturnim predalčkom samskosti ali se jim, nasprotno, skušajo upreti?

Samskost oziroma »singleness « je sicer nedorečena kategorija. Jill Reynolds se zato v uvodnem poglavju sprašuje, ali obstajajo prava leta za to, da nekoga označimo kot samskega (»single«). Ali v to kategorijo sodi 14-letno dekle? Kaj pa 80-letna ženska, ki je pravkar ovdovela? Za termin »single ( $\mathrm{ki}$ v slovenščini žal nima ekvivalentnega prevoda) je značilno, da ga spremlja cel kup konotacij, ki tako $\mathrm{v}$ prvem kot $\mathrm{v}$ drugem primeru očitno ne držijo. Avtorica je zato pri iskanju sogovornic postavila naslednje kriterije: da so samske, ločene ali ovdovele več kot dve leti, da ne živijo $\mathrm{z}$ nikomer $\mathrm{v}$ intimnem partnerskem razmerju in so stare med 30 in 60 let.

$\mathrm{V}$ drugem poglavju sledimo diskusiji teoretičnih konceptov, na 
katerih je avtorica zasnovala svojo raziskavo in konec koncev svoj in nov model feministične diskurzivne analize. Iz izjemno obširnega nabora analizirane literature je identificirala tri različne pristope $\mathrm{k}$ razlaganju identitete in samskosti: modele življenjskega cikla, psihodinamične modele in izkustvene modele. Kot razlaga avtorica, modeli življenjskega cikla po literaturi o družinski terapiji predvidevajo, da obstajajo univerzalni vidiki razvoja, ki predpostavljajo potrebo po adaptaciji spremembam na ključnih tranzicijskih točkah, kot so dvorjenje, poroka, rojstvo otrok, čas, ko otroci zapustijo dom, in upokojitev. Gre za družbeni model identitete, utemeljene na kulturnih pričakovanjih do posameznika, toda $s$ predpostavko, da je treba nekatere vidike razvoja izpogajati, kar je odvisno od kulturnega konteksta. Jill Reynolds je do teh modelov kritična, saj so zakoreninjeni v ciklih, ki jih doživljajo družine, in je tisto, kar morajo potemtakem samski izpogajati, njihova deviacija od normalnega razvoja družinskega življenja in vzgoje otrok. Tudi psihodinamične modele, ki temeljijo na Freudu in psihoanalizi, zavrne, saj so preveč individualizirani, da bi bili preverljivi. Največ literature temelji na iz- kustvenih modelih in tako je svojo analizo zastavila tudi sama. Njen pristop predpostavlja, da najdejo ženske $\mathrm{v}$ stanju samskosti različne pomene, vendar $\mathrm{v}$ pripovedih različnih žensk kljub temu obstaja nekaj skupnih tem. Kot pravi, gre za emancipatorni model, ki ne išče pomenov onkraj zavesti.

$\mathrm{V}$ naslednjem, tretjem poglavju Jill Reynolds analizira štiri interpretativne repertoarje, ki so jih sogovornice najpogosteje uporabljale, ko jih je povprašala, naj opišejo sebe in podobe samskosti, ki jih imajo same ali mislijo, da jih imajo drugi. Sogovornice so samskost dojemale kot deficit, kot socialno izključenost, kot neodvisnost in izbiro ter kot osebni razvoj in dosežek. Večina žensk je uporabljala vse štiri repertoarje in gradila močno polarizirane konstrukcije samskosti kot stanja, ki je bilo hkrati globoko problematično in obenem polno potenciala. Jill Reynolds vzroke za takšne nasprotujoče si odgovore vidi v dilemah, $s$ katerimi se soočajo samske ženske. Če se odločijo, da bodo samskost konstruirale zelo pozitivno, $\mathrm{z}$ izpostavljanjem izbire in neodvisnosti, osebnega razvoja in dosežkov, se je zelo težko premakniti iz te kategorije. Če po drugi strani brez sramu govorijo o svoji želji po zvezi, tvega- 
jo, da jih bodo drugi konstruirali kot »obupane« in neuspešne pri iskanju moža. Edina pozitivna strategija, ki pa jo je uporabljalo majhno število žensk, je bila, da so razvile bolj refleksiven odnos do samskosti.

$\mathrm{V}$ naslednjem poglavju sledi diskurzivna analiza vprašanj in odgovorov o partnerskih odnosih in samskosti. Avtorica je iz intervjujev razbrala tri okvire, kako so sogovornice razumele svoje življenje: kot življenjski krog (obstaja čas za imeti odnose $\mathrm{z}$ več moškimi, imeti resno zvezo, otroke itd.), kot življenjske dogodke (ki so vplivali na nadaljnji potek biografije) in kot razvoj (od divjih dvajsetih do veliko bolj urejenih štiridesetih). Skozi diskurzivno analizo enega intervjuja (ki jo podkrepljuje tudi z izseki iz drugih) avtorica dokazuje, da morajo samske ženske pri prikazovanju svoje osebne pripovedi uporabljati različne retorične prijeme, da bi opravile s prevladujočim kulturnim življenjskim scenarijem zakonskih in družinskih odnosov, ki progresivno pelje do cenjene končne točke.

Ne glede na spremembe $\mathrm{v}$ zvezah še vedno obstaja predpostavka o življenju v paru kot delu normalnega odraslega življenja, nadaljuje avtorica v naslednjem poglavju. »To za ženske, ki ne živijo v paru, pred- stavlja dilemo. Kako naj se počutijo zadovoljne same s seboj in imajo opolnomočeno podobo? Kako naj s tem upravljajo $\mathrm{v}$ lastnem govoru o zvezah? « se sprašuje Jill Reynolds (96). Vprašanje samskosti odpre kot vprašanje izbire, vendar je ne zanima toliko, ali so ženske izbrale, da bodo samske, ampak kako v pogovoru ravnajo s tem vidikom. Takšen pristop avtorica utemeljuje s številnimi empiričnimi študijami, ki so skušale odkriti, kolikšen del samskih je to po izbiri, vendar so bili odgovori preveč kompleksni, da bi to ločnico lahko potegnili. Avtorica zato pripovedi sogovornic analizira po štirih značilnih tipih odgovorov v sklopu pogovora o samskosti kot izbiri: »želim se počutiti izbrano" (od moškega, ki me bo poročil), »nisem čutila potrebe« (kar je manj pasiven odnos kot v prvem primeru, vendar izraža obrambno pozicijo), »želim si biti v partnerskem razmerju « (izraža trenutno željo po partnerstvu, ki pa še ni obrodila sadov) in "preprosto se ni zgodilo« (lahko pomeni najbolj pozitiven pristop, a včasih izraža tudi vlogo žrtve).

$\mathrm{Na}$ enak način je avtorica analizirala pripovedi o preteklih zvezah. Identificirala je naslednje ponavljanje odgovorov. »Nisem izbrala pravega « (ženske pripovedujejo o mo- 
ških kot osebah, ki te razočarajo, se upirajo enakopravnosti, so nasilni ali te skušajo celo ubiti; ženske se pogosto samoobtožujejo, da niso pravočasno prepoznale znakov). Intervjuvanke so izpostavljale tudi zveze z moškimi, ki niso bili na razpolago. Poročeni moški je bil za eno od njih denimo »varen«, ker ni želela, da bi zapustil ženo in ni bilo treba sprejemati odločitve. Tretja skupina je o preteklih zvezah govorila $\mathrm{v}$ smislu Becka in Beck-Gernsheimove, Baumana in Giddensa: »Po petih letih sem se ga naveličala « ali pa: »Zveze niso namenjene temu, da bi trajale večno, ampak tako dolgo, dokler si oba želita biti v njej«.

$\mathrm{V}$ šestem poglavju (Vsakodnevne politike samskosti) avtorica analizira svojo vlogo $\mathrm{v}$ intervjujih in se sprašuje, kako so njena vprašanja in način, kako jih je zastavljala, vplivali na odgovore o identiteti sogovornic. Sprašuje se o vplivu svojih lastnih izkušenj s samskostjo in vplivu svojega prepričanja, da je biti samska ženska družbena identiteta, ki po določenem življenjskem obdobju zahteva razlago. Tudi če se je sama trudila zagotoviti udoben prostor, neobremenjen s stigmami, je včasih prihajalo do težav v interakciji, ugotavlja skozi diskurzivno analizo pogovorov o samski identiteti, ki jo je - po intervjujih sodeč - težko definirati ali ji pripisati enotne pomene.

Tako kot $\mathrm{v}$ celotni monografiji je Jill Reynolds tudi v tem poglavju metodološko konsistentna. Podaja pregledne analize uporabljenih (in zavrženih) teoretičnih in metodoloških pristopov, vključno $\mathrm{z}$ razumevanjem diskurzivne analize same. $\mathrm{Na}$ tej podlagi $\mathrm{z}$ najvišjo mero natančnosti in občutljivosti analizira pogovore s samskimi ženskami. Ne obravnava jih kot neposredne informatorke in poročevalke, ampak raziskuje, kako identiteto samskosti uporabljajo v govoru. Nikoli ne obsoja in v tretji osebi analizira tudi svojo vlogo v intervjujih.

$\mathrm{Z}$ monografijo The single Woman Jill Reynolds ni le zapolnila ene od vrzeli na področju raziskovanja marginalizacije samskih žensk, ampak je ustvarila dobrodošel »metodološki učbenik« za vse, ki raziskujejo v humanistiki. 